\title{
Prison Days: Observations and Reservations of a Public Scholar
}

\author{
Yvonne Schwarz Hammond \\ Rowan University, US \\ hammondy@rowan.edu
}

Around 2016 the Appalachian Prison Book Club (a non-profit organization that sends free books to incarcerated persons in a six-state region) extended efforts to reach readers inside prisons by supporting a men's book club at a medium security prison for just over two years. As a prison studies scholar and activist, I began working with APBP during the early years of my graduate studies and was offered the chance to co-facilitate the book club. In this essay I explore observations about labor, service, and gender made during this two-year period working simultaneously with incarcerated men, prison staff, and a university. Maintaining the book club shaped my experiences in graduate school, redefining my understanding of scholarship, especially in terms that highlighted the conflicted and complex relationships between the two institutions that made demands for my education, time, and labor. Rather than establishing a firm trajectory, my academic labor shifted between service and scholarship, exposing anxieties about women's roles in both academic and prison spaces.

Keywords: prison; gender; book club; public scholarship; Appalachia; service learning; academic labor

If any day it will snow heavily in the Appalachian Mountains, it will be a Wednesday-the day scheduled for the Men's Book Club at a federal facility tucked among reclaimed mountaintops leftover from coal days. Prison days are unlike other days; prison days are always stressful, pairing unpredictability with a long list of things to remember. Some of what I bring is not unlike any other teaching job: books for our next meeting, paper, pen, notes anticipating questions, some research for context, a snack and a bottle of water that must wait for me in the car. But I must also remember to wear long pants and a professional blouse, no underwire bra, no jewelry, and Oxford-type shoes; I need to grab my driver's license, but not my wallet, an agenda book, instead of the electronic version in my phone. I have tried to use my organizational skills to reduce the stress, thinking that luck would favor the prepared. I purchased what I refer to as my 'prison clothes.' I keep all the papers, pens, and notes in a canvas shoulder bag in plain sight hanging on my bedpost. I have a designated area of my bookshelf for storing the texts I will slowly bring into the facility (but I have also been known to just leave the boxes of books in the trunk of my car). Despite my best efforts I cannot foresee the lockdowns, ${ }^{1}$ or anticipate the last minute decisions about programming made from inside the prison, the potential for car troubles, and especially not the weather; some days we do all we can to prepare and we aren't able to move behind the wall.

While organizations like Free Minds ${ }^{2}$ organize federal book clubs from outside of prisons, the Appalachian Prison Book Project (APBP) ${ }^{3}$ has earned the rare opportunity to facilitate a book club inside. Having worked with APBP early in my graduate career, I had the opportunity to build and sustain a non-profit organization,

\footnotetext{
${ }^{1}$ Lockdowns, a period of time during which incarcerated peoples are not permitted to leave their cells, occur with frequency and without explanation to volunteers. Volunteers cannot verify lockdowns, and thus cancelling programing for lockdowns (real or not) can be used as a way to control contact between incarcerated peoples and volunteers.

${ }^{2}$ A nonprofit book club and writing workshop operating in the Washington DC area.

${ }^{3}$ The Appalachian Prison Book Project is a nonprofit organization that sends free books to incarcerated peoples in a six state region of Appalachia: West Virginia, Virginia, Ohio, Kentucky, Maryland, and Tennessee.
} 
which helped me imagine the impact of my studies outside of the university and define my identity as a public scholar. In this essay I will trace my history with the activist-based volunteerism I found at APBP, and then turn to a discussion of sustainable work-life balance that has been complicated by the blurred boundaries between my service and my scholarship. Being a public scholar means redistributing my labor to the prison, to the guards, to the incarcerated men, and to the APBP organization, all of which highlights the extremities of time, energy, and emotional impacts. The redistribution of my academic labor reveals much about both institutions-the prison and the academy-exposing the parallels in a way that produces discomfort for me and occasionally highlights my fears (borrowing from Audre Lorde) that I cannot use the "master's tools" to break the "master's house."

Public scholarship is that tricky space between campus and community that land grant universities such as West Virginia University are required to serve. In choosing to serve prison populations I strike a shaky balance between the federal prison and the academy for which I teach, my beliefs as an activist, and my future career. I have found that my training as a literary scholar provides me the ability to guide discussions and to choose books and theories that interrogate the diverse and varied apparatus that criminalizes the men that circle our discussion table. My scholarship in prison studies prepares me to witness the inequity at the facility, and to some degree, aids in my efforts to negotiate a "peculiar institution" (Garland). However, no training or reading has prepared me for the complex social, cultural, and ethical dilemmas the book club members and I face by asking for sponsorship to teach inside. Above all my desire to return in two weeks for another session silences me-I cannot always or perhaps ever fight the system from within the walls.

When I first began working with the book club I had a well-defined idea about the moral necessity of reading books inside, but almost two years later I began to recognize the toll of public scholarship. The toll included rethinking the ethical implications of carceral studies. I feel committed to limiting my voice in the field. I do not want to speak for the imprisoned; they are very capable of speaking for themselves. Furthermore, my efforts to educate depend, at least on some level, on my complicity with elements of the criminal justice system. My service to the incarcerated men prison has challenged me to reconsider the varying roles I occupy in order to facilitate a book club inside a federal prison, including, to my surprise, my role as a female scholar doing service work in a male facility. My identity as a scholar and volunteer cannot be separated from my sex and gender, and my experiences with volunteer training and other sexualized encounters exemplify the ways in which certain policies and procedures pre-emptively criminalize volunteers. As I continue to contextualize my work within the larger body of work about prison education, my primary concern circles one simple premise: prison harms that which it touches.

\section{The Appalachian Prison Book Project}

My story actually begins about seven years ago when I signed up for a course advertised as the penalty of death in $20^{\text {th }}$ century literature. Our readings opened doors to a space I had never been, nor had ever given much thought; however, as we came to learn, prison is never far away. When I read Willie Francis' essay and A Lesson Before Dying I could put distance between myself and the contexts of the criminal justice system, after all I neither knew no one who had been put to death, nor had I ever witnessed an execution; but when I read Mikal Gilmore's Shot in the Heart I suddenly remembered the family members who never escaped the revolving door to prison. My uncle spent most of his life in prison; he was in and out of juvenile delinquency housing units before his teens. My dad never knew his brother outside of prison clothes. I also had a cousin who was known to visit just after his releases, brief breaks between prison stints. For what? I never knew. In fact I didn't know him at all. My uncle and cousin's stories were never fully available to my siblings or me; however, we knew enough to know that we shouldn't be "like them."

Stories change people, and when I cracked the cover of Norman Mailer's Executioner's Song the summer before I began the prison literature course my thoughts about prison were nascent, underdeveloped, sad, shocked, and stunned. I think the students in the course traveled through the stages of grief over and over that semester, mourning the deaths of Willie Francis, Gary Gilmore, the Scottsboro Boys, Caryl Chessman, and others. Looking back I cannot imagine how our instructor, Dr. Katy Ryan, led a class knowing the grief she and her students would experience. She knew before she began what she would feel and she knew she would have to help others process those emotions as well. I decided at the end of the semester, having written an incomplete paper about rape in prison, that I needed to do something more than write a paper, so I was persuaded to come to a board meeting for the Appalachian Prison Book Project.

The mission of APBP is simple: send books to incarcerated men and women their request. Our training is a series of simple steps: open letters, highlight requests, match the request to the best of your ability with the materials available on the shelf, record the data, wrap the book in brown paper and copious amounts 
of tape that never seems to stick despite being sticky enough to stick to every surface but the brown paper, and address the package with a note that says "please ask for more; I hope you enjoy this book friend." I embraced the simple act of opening letters and sending books. I brought my then pre-teen boys to the center and they too opened and read letters. I didn't think about what it would mean to them, later as young adults, to have been raised within APBP activism.

The simple act of sending a book into prison, as it turned out, is a political act. With increasing urgency more and more states are banning certain book titles from finding their way into prison, and more and more states are banning book projects like ours from sending books inside. My children became invested in what did not initially appear to be an act of subversion, but instead a path for meeting people they would never meet in person. The letters sometimes made them upset. My son donated many beloved books because it hurt him so much to read letters requesting The Hobbit or Dungeons and Dragons. He always told me that he could replace the books, but that everyone deserved to be able to have a fantasy escape. I agreed. My children learned to advocate for criminal justice reform and argue with classmates about police surveillance in their high school. They look at their friends who struggle with drug abuse and try to counsel them as only teen boys can do. At nineteen and seventeen they already know more than I did at their age; prison breaks more than it builds.

A year after I joined APBP's volunteer list I was awarded a summer internship grant through West Virginia University that allowed me to work with APBP for a sum much larger than the traditional graduate teaching stipend. The program was designed to address the disparity between alt-ac and academic jobs by offering students the opportunity work outside of academia (and as I write this I now wonder if there wasn't some sort of ulterior message in the pay differential). I had just ended the second year of my PhD program and had not really figured anything out. I decided to do all the things, and because the prison literature course was still fresh I felt impassioned by APBP's mission.

At the time APBP had run out of funds and there was a spending freeze. It's really hard to send out books when you don't have money for postage, so to make my hours count, myself and another intern cleaned our storage space, hauling hundreds of hard-used books to the recycling center and the farmer's market. Our organization depends on donated books supplied by local community members (and of course the English majors drawn to the work), and while most individuals donate with a kind heart, our shelves are often laden with well-intentioned texts that fall into one of three categories: a great book to send to the right person, a book that has probably been in the damp basement too long, or an effort to impress Christianity as the solution to a "life of crime." A good portion of our labor is spent organizing the culling shelves to maximize our limited space, a single room in a beautiful, historical home near a college campus.

My colleague and I were tasked with finding books we could not send out: hardbacks, books with sexual covers (think D.H. Lawrence), or books with questionable material, which allowed us to make money by hauling the extra stock to the Farmer's Market. Every other week we set up a small shelf and tried to convince passersby to buy a book or donate a couple of dollars. We usually made enough money to send a box of books; I learned that a post office box of books costs about $\$ 60$ to ship. I learned that a single book cost about $\$ 2.58$ and two books of similar size cost \$3.14. I learned that it was hard work to haul books up and down two flights of stairs (even though it was a more familiar labor than writing grants). Books were heavy. My hands were dry. My nose would sometimes weep; my hands would sometimes crack. Some days the grant writing we did in tandem with the book hauls was easier; but most of the time it wasn't. As a writer I felt like grant writing should have been easier, but convincing foundations that imprisoned people need help is tough sale, particularly when you lack the training it takes to negotiate the complicated systems required for money.

After the summer internship, I remained an active part of APBP, and as I grew as a scholar I grew alongside APBP. It wasn't long after this lean summer that APBP was awarded a decent grant and this was followed by a large donation, which has been followed by a series of large donations and more grants. In some ways the money mirrored my own journey, the more money we found, the deeper I became involved in advocacy. However, my work with APBP has always been what I lovingly refer to as "my other life." My days and weeks were structured by teaching, advising, researching and writing a dissertation. In my other life I called for APBP meetings, helped support prison symposiums and service learning weekends for visiting undergraduate students from Virginia, trained new volunteers, organized training schedules, hosted information sessions at various panels, attended prison studies panels, and imagined how to grow our grassroots outreach into a larger social justice organization. My other life did begin to blend with my academic work when three years after the prison literature course my unfinished paper found a home in an edited collection. This came on the heels of a summer research assistantship that sent me into the archives to look at a rare find-a 
prison journal published inside the walls by incarcerated men. In those moments the fractured parts of my academic career came together; but I couldn't maintain the balance.

\section{Service or Scholarship?}

Somewhere, in what is quickly approaching a decade long journey, I discovered that my academic self was not satisfied with learning and reading theories without pairing theory with activism. But as my career developed it became increasingly more difficult to balance the demands of activism with the demands of academia. The cracks began to become more apparent the final year of my PhD program. I felt very guilty about taking a leadership role in APBP that year knowing that I could not put a great deal of time into the organization (though my mentor reassured me that APBP would be there no matter what). So I continued. A year before my defense the federal facility near me asked for facilitators for a men's book club. A colleague, Dr. Valerie Surrett, and myself were offered the chance to organize a small group of volunteers to lead discussions about books. At the time we had no idea what this would look like, but we said yes, enthusiastically, without any hesitation, yes.

APBP and the men's book club allowed me to translate the theories we studied in the classroom into real world situations. The spring I finished my dissertation I heard the term 'public scholar,' and I realized that term could be the way to link my service work with my scholarship. My need to redefine the service/scholarship tension developed (in part) as a response to witnessing and participating in academic classrooms. I felt we were always lost in repeated deconstructions of American 'problematics' without any profound efforts to respond. We didn't leave our seminars with an action plan, and I am not sure anyone told anyone anything about our conversations. So, like the proverbial tree that falls in the woods, if a bunch of academics are talking and no one is there to hear them, did they ever make a sound?

In contrast to the campus classrooms, in prison I participated in conversations with men whose experiences with the world had shaped skeptical readers like none I had ever encountered. I conversed with readers who found Barbara Ehrenreich's exposé about living in poverty laughable; they couldn't figure out why she didn't just talk to someone in the projects. They really couldn't understand how she claimed to be living in poverty when she always had a means of escape. They said she should have given the money to their "mamas" who would have told her how to survive with nothing. I tried to persuade reluctant readers that Fight Club establishes an important critique of toxic masculinity in the age of neo-liberalism; they remained unconvinced and renamed it "fart club." I talked to readers who spent almost six months working through Bryan Stevenson's Just Mercy, far beyond what any undergraduate or even graduate classroom would ever discuss a single text. In the prison I talked to men who can deconstruct just as well if not better than my graduate school cohorts from inside prison walls, who make demands of literature and literary study that we don't always see in graduate student classrooms. There was something indefinable about book club, something that cannot be captured in any other space.

I had always imagined the overlap between my life as an academic and my other life meeting through teaching. As a facilitator, my role at the book club was primarily to lead discussions and help choose booksnot to teach; but there was no way for me to talk about books without bringing my training to bear. I failed to anticipate what it would take to read a book every other week in a year focused on finishing and writing a dissertation. I failed to consider the impact of what amounted to another prep in a year where my teaching load was a 2-3, with three new preps. Above all, I failed to comprehend the emotional, physical, and intellectual labor that I brought to the book club. At the time I didn't yet see the book club as a piece of my scholarship; it was a service I provided, a part of my other life, the life in which I volunteered my time and gave freely of my labor. I had always already understood the connection between labor and APBP because I had not forgotten carrying those books back and forth, up and down stairs, to and from post offices. Academic labor, as I have learned, doesn't look like any other labor. Academic labor includes the time to read and research and the time needed for self-care to develop new connections; it's much more difficult to see this labor and even harder to protect it.

As a graduate student you are conditioned not to think about labor. You don't think about the exchange of labor between the university and the graduate student because you are so happy to have been accepted to the program. You don't think about volunteer work and the impact on your studies because as a humanist you believe in social equity. Graduate school is a type of apprenticeship; you do all that you can to gain the experiences needed to be a professor regardless of the labor required. For myself, I didn't think about my time or the value of my time because I hadn't yet experienced a true lack of time (and believe me, I know what I am saying, but truly I look back and feel like I had so much free time in graduate school). The last year of my PhD was impacted by many factors-teaching, two children, life, dogs, service learning supervising, 
a new TA-but no matter how many times everyone asked, I refused to step away from the book club. The book club was usually the only time that I had to myself, which further complicated the imagined margins separating the various roles and identities I fostered. The book club was my time to talk about books in the most pure and English-like fashion available outside of the already long-completed seminar classes. In the early days I didn't recognize book club as service, labor, or scholarship.

The cracks between my academic and activist identities grew into rifts the fall following my graduation. I kept coming back to the same questions: what is the labor of the scholar and who owns that labor? I cannot place the blame on any one thing; however, teaching overload challenged me to think about my time more acutely than ever before. I taught six classes, one of which was a new prep. I continue to co-facilitate the men's book club, I remained president of APBP, and I continued a limited, but robust, research effort to study prison related topics. Consequentially, I became more aware of the value of my time and my thoughts. My labor was counted carefully and measured by the university to assure that I didn't reach full-time. My pay, no longer a stipend, was now based on a per course assignment calculated on the erroneous assumption that a twenty-two seat section of a writing class can be isolated to ten hours a week. My days began early and ended just shy of twelve hours. I sometimes forgot to eat; I almost always forgot to use to the bathroom. People close to me couldn't understand why I continued to lose a full day every other week to fight to get into a prison. They had never met the incarcerated men with whom I worked.

Despite all of the excellent work the book club members do (or perhaps because of it), I believe there is no escaping the issue of labor and the unseen losses experienced by those willing to work to go inside prison. For me this was most often revealed through interactions with prison staff. Not all prison staff were hostile to APBP volunteers, and in fact, many supported our work and actively looked for avenues to staff programming. Occasionally prison staff members joined book club even though they had not read, drawn in by the desire to participate in enthusiastic conversations. Their participation complicated our dynamic; what's said in book club has real consequences when communicated to prison staff. When we read and discussed Cornel West's Race Matters, I thought, "This is it. This is the day that we will be in trouble." Ironically it wasn't that day or any one-day in particular, but rather a change in staffing introducing a person who regarded all literature with distrust that broke us.

Having prison staff join our discussion circle also complicated the notion of service, which highlighted a troubling paradox (and prejudice) about my teaching inside. My service was freely given to the incarcerated men because they are indigent, because I felt they deserved it, because I had studied all sorts of narratives that told me those in prison frequently had missed out on education. Prison staff had the freedom to take a course with me; yet, I am aware that most of the staff at the facility where we worked had little opportunity for education. The pay in West Virginia is embarrassingly low for prison staff and very little education is required. One of our escorts often lamented that they had always wanted to go to school to become a historian, but never could afford to go to school. However, I was still annoyed when they felt entitled to take from what I had given to the men, including the free text. My annoyance extended and grew each time staff suggested that the men could recreate book club without our leadership. While on the one hand they indirectly recognized something special about our meetings by joining us, they failed to realize the roles we played in fueling those conversations. Unaware of how our training impacted and skill sets impacted our work inside, the staff dismissed what they witnessed as simplicity. It was never simple.

Alongside my ire, I found myself increasingly obsessed with the monetization of my education, which cast a shadow on what I had admired most about my professors-they seemed to share their ideas and knowledge without reserve. And yet, I now know that in choosing a career as a professor I am required to think about my work as a currency: my thoughts, pedagogy, and service-all are worth time and therefore exact a cost. The university owned 10\% of my service, and I began to wonder if in volunteering through APBP whether or not it belonged exclusively to the incarcerated, or if the staff had a right to "free education" as well? My discomfort with sharing my labor revealed a prejudice in my thoughts and set up the type of binaries I usually try to dispel: guard versus an ill-defined "us." I became conflicted about the appropriation of my labor, usually in moments that pitted my labor at odds with the work of the prison. To some degree my labor involved working with the staff to assure that we would be welcomed in for another week. This looked like lunches and coffee dates, social events that made my stomach churn knowing the men inside were eating yet another bowl of ramen with jailhouse hot sauce. In those moments (and others) I felt that I was valued as long as I was complicit in the system.

The question labor was equally complicated by my position as a lecturer and the ways in which the academic institution benefited. Not only was I a member of a high profile organization, teaching courses that were drawing students into the English major and opening doors for my students to visit with guests 
such as Bryan Stevenson, but I was also teaching at adjunct pay. West Virginia University (WVU) only owned part of my labor-the labor of my teaching that that happened Monday through Friday somewhere between 8:30 and 3:30-but WVU benefited in ways that could not be documented. I knew that this wouldn't always be the case though; a tenure-track job or a non-profit position might change the time available to serve.

However, when your scholarship involves public service, it is so much harder to draw the boundaries between service and scholarship, and much harder between work/life balance. As a single mom I faced innumerable challenges, not the least of which were two male dominated institutions eager for my time, but unwilling to provide the support needed to do the work. Instead of assigning me Tuesday/Thursday courses (which would have consolidated my teaching and allowed me time for home), I had to accept the assignments convenient for the school. Similarly, book club had to meet at times convenient for staff regardless of the time needed to travel or get my kids off to school.

It wasn't just logistics threatening the balance. My troubles getting into the prison impacted my weeks; the tears I shed from frustrations don't stop falling because I had class. Conversely my teaching responsibilities didn't end because I had blocked the day to travel to the prison. It wasn't always about free labor; it was also about self-care and sustainability. I found that the support for my labor was very narrowly defined and support for my volunteerism/service for prison didn't register as such. I asked myself: What labor should be free? What defines service? I am still unsure, and I am plagued by fears about how to shape my career such that I can find a tenure track position that will recognize the value and importance of my work in prison. At the time I didn't know how much longer I could live without such recognition, but unfortunately the recognition I received was not what I had hoped. Something had to give, and something did.

\section{Uneasy Observations}

My personal and academic preparation and education failed to anticipate the deep pain of realizing the ways I would have to participate in order to serve. My reflections about my experiences converge in my uneasy observations about the ways in which my gender established tacit expectations for my time, my labor, and my relations with the prison. There are times when I fool myself into believing that I could have sustained the lifestyle I had cultivated for longer were it not for a change in staff that brought knocked the house of cards to the floor. As I reflect now, four months away from my last visit with the book club, the fragility and vulnerability was evident from the day we stepped into the facility.

Unlike others (having been married to a former prison guard) I was aware of the other side of the wall-the people who are imprisoned, but not for having been judged for committing a crime. In West Virginia prison staff start at just under $\$ 23,000,{ }^{4}$ which means that they are making about $\$ 13$ an hour. Worse, in December 2017, Gov. Jim Justice declared a state of emergency over short staffing at state jails. To address the issue the secretary of Military Affairs and Public Safety authorized the West Virginia National Guard to help staff juvenile and adult facilities and increased the use of lockdowns until long-term solutions could be developed (Baucher). Stretched thin, the staff with which I worked communicated their frustrations. They want to do more; they want the system to be more humane. One man wishes he had had more time for education and in another life, as he calls it, he would have been a history professor. The staff too are impacted by rules and decisions outside of their control. For example, the recent turn to private prisons is affecting federal funding. Incarcerated men are already being moved out of federal facilities to beds in private prisons. The staff shares their concerns with us knowing our education and familiarity with the systems. Though I have met individuals who chose to interact with guards and staff as little as possible, I can't help but see the ways that these men and women are equally trapped by this 'peculiar' system. Often the contextual differences between the incarcerated men and their keepers are minimal.

My moments of finding empathy with the staff felt increasingly more apologetic, particularly as I moved deeper into higher education in prison. I found groups who argued that the work of prison education included those running the facilities. Their rationale centered on the idea that in order to make lasting change all those participating in the criminal justice system needed to be included in reformation efforts. Persuaded by this notion, I sought additional training for teaching inside based on stricter boundaries between teaching and activism. Rather than drawing me into prison work, the training left me disenchanted. I felt as though I was watching academics take advantage of imprisoned peoples, parading them around to exemplify sociological and criminological principles, while simultaneously asking them to verify the humanity of

\footnotetext{
${ }^{4}$ As reported by the Charleston Gazette, July $7^{\text {th }} 2012$ and the Bureau of Labor Statistics (2016).
} 
incarcerated people. The zoo-like quality of the teachings evoked a dark cynicism, and I decided that for a while I needed to leave the inside and rethink my role. I found that I can neither fully condemn nor forgive my own or others collaboration with the criminal justice system; I haven't been back to a prison since.

The dissonance preying upon me intensified with the unease I experienced by tolerating sexism and surveillance. To be clear I am not only speaking to the sexism produced in spaces that encourage toxic masculinity, but also in all the other spaces in which a single mother such as myself was expected to operate. In short, while the prison wasn't the only way I experienced sexism, it was a way that I invited sexism into my life. As a woman I am frequently asked if I feel unsafe or scared going into prison. I always answer no, but my answer is not entirely true. I don't fear the incarcerated men with whom I work; I do fear the staff occasionally. In training a man once told us that he couldn't wait for volunteers to make a mistake. He told us he would proudly attend our prosecution hearing for violating the rules and that he would count it as "another notch in his bedpost." He seemed to understand the sexual connotations of his analogy as he spoke to a room of twenty plus volunteers; eighteen of the twenty that day were women. I usually leave the prison with a stress headache. I am tense because I am not always sure what I might say or do to inadvertently betray my real thoughts about the entire system.

The sexism I experienced in the prison parallels that of the academy. Recently academic news sources like The Chronicle and Inside Higher Ed have reported that women not only "shoulder a disproportionately large workload at home in ways that disadvantage them professionally," but also "perform 30 more minutes per week of service than men and 1.5 more service activities per year than men" (Flaherty). And this gender gap isn't translating into more opportunities for promotion, and in fact, the disproportionate share of departmental service duties-work that needs to be done-"doesn't carry much weight when it's time to decide who gets promoted" (Jaschilk). These reports don't surprise me. As a female I am aware of the gender gap in pay and labor. I am familiar with students' expectations that female professors nurture and that some departments expect women to do more emotional labor. As a graduate student I was aware that in a department of just under forty members, only two women held full professorships and only one was in a position of leadership. However, the problem of sex and gender in academia aside, attending conferences about carceral studies drew my attention to the disparity between male and female volunteers. Of the ten plus volunteers consistently participating in the men and women's book clubs with APBP, only two are men.

Not only is there disparity between the number of volunteers and the amount of time spent volunteering, sex and gender also plays a part in mediating the interactions of my service work. I found it more and more difficult to turn away from the evidence that sex and gender influenced all of the relationships at the prison. Admittedly, having been married to a soldier, I was prepared to witness and experience a certain level of misogynist behavior produced by masculine-dominant institutions. However, I truly wasn't prepared for the ways my body would be surveyed. The list of rules for men's clothing is relatively short: long pants, no jeans, no hoodies, professional shirt, no watches. Most men have to remove their belts and shoes to pass through the metal detector, but so do women. The list for women is much longer: no dress or skirts, no skinny pants, no jeans, no heals, no open toed shoes, no jewelry, no underwire bra, no cardigans, no hoodies, no hats, no sunglasses, no low-cut shirts, no tank tops, no tight shirts, no capris, no shorts, no yoga pants/sweatpants/leggings. The rules vary per facility and change without little or no notice. In the span of thirty minutes at a visit to a facility in Pennsylvania, female visitors were provided three sets of clothing rules.

Clothing is the most obvious and tangible way volunteers meet with ill-defined and constantly changing rules for femininity. When we walk into the doors of the facility the women must lack femininity. In general shirts need to come to your collarbone, below your waist, come to the elbow, and be loose. Our clothes must be baggy and black; professional, but not pretty; our identity must be 'generic volunteer.' During our volunteer training we are told that if we feel like we look good we are "wrong." The trainers emphasize that we should always remember where we are, but to be sure if we forget there are constant reminders. As a female academic it is difficult for me to process all the ways female bodies are surveyed.

I haven't been brave enough to ask about the origin of the clothing policies. In training there is only a very brief allusion to clothing and behavior rules as a means of upholding professionalism. However, there are other conflicted messages about safety (our clothing choices must be made with the idea that anything can happen and we might need to run away), about discouraging familiarity (even though federal reports show that sexual abuse by staff is the most common), ${ }^{5}$ and about protection (from interactions that are

\footnotetext{
${ }^{5}$ See Bureau of Justice Statistics Prison Rape Elimination Act of 2003 and U.S. Department of Justice Sexual Victimization in Prison and Jails Reported by Inmates, 2011-12 and Update.
} 
never unsupervised). Rather than discouraging sexism, the rules about clothing and mannerisms made me more acutely aware of and anxious about sexuality inside the walls. Moments such as when I have heard staff adopt a "feminine" type voice to make jokes about homosexual behavior, or when hearing staff mumble under their breath about "do-gooder" women fueled my anxiety. Sometimes I helped others process their own sexualized encounters with staff. On one occasion a female volunteer was disciplined for her hair tie breaking; when she swept back her hair it looked too sexy. Another female volunteer was disciplined for not covering up her heavy sports bra strap. Another female was disciplined for leaning in to listen to an incarcerated man's explanation in a crowded, noisy room. She was too sexy and "teasing."

In my scholarship I had already long ago learned that prison is about punishing the body, but I was not prepared for the ways it would punish my body. In the summer my prison clothes were very hot, in the winter just a tad too cold. The professional pants are always uncomfortable after sitting for a couple of hours with no water to flush my system. Sometimes we would be prevented from leaving because of staffing and could not eat; sometimes we shared food with the men who generously pushed their fresh fruit our direction, saving us from the fields of brown carbs that decorated their plates. My physical discomforts were mild in comparison to the hyper vigilance I maintained policing my body, my voice, and my behaviors to make sure that I was not acting sexy, flirty, or pretty. My sexuality was always on trial and there was no escaping what felt more and more like a spectacle. We volunteers laughingly referred to the Netflix series Stranger Things by calling prison the Upside-down. Nothing made sense and everything felt wrong.

Sexuality in prison plays a crucial role in determining your place in the hierarchy. I have written about the way prison rape in mainstream culture acts as a means to punish men who step beyond the pale; rape seems to be the way patriarchy punishes men for violating codes. This ignores the role of consent, and of course varied sexual relations, but my lingering thoughts about sex as punishment haunt me when I think interactions with staff who believed my volunteerism made their job harder. We were guilty of making the men desire us, making them laugh, and/or increasing disruptive behavior. We were kept out of the facility during periods when drug use was a problem because we could have been the source for the drug availability. Volunteers with bi-weekly programming were shifted out of certain meeting areas into others because one room was too large and thus increased the likelihood of a sexual encounter; another room's tables were tall enough to hide sexual acts. It was suggested that my colleague and I were performing sexual acts on the men during book club, so, ironically, they moved us into a small room with a closed door and watched us by camera instead of staying in the room where the staff could sit comfortably among us. Our sexuality was again on trial.

As tensions and distrust increased (in spite of the changes made to safeguard status quo at the facility), the stress on me became unbelievable. I began to cry often and mentioned quitting for the first time in my career. As an organization APBP gathered together attempting to try to find solutions with our community members. We knew that the prison staff both desired our knowledge and ability to teach, and distrusted us for our knowledge and what we were capable of teaching. The distrust had always been present, a hint that our project was always at risk. It began in the first weeks of book club with the request for the facility to keep the books that we had brought in for the book club members. What the facility labeled as "gifts," and therefore a violation of federal policy, APBP defined as education materials. The issue was never resolved and foreshadowed the conflicts that eventually ended the book club.

My uneasy observations about working at a federal facility have to be measured and careful; I have been told that they will continue to watch me and the work I do with a not so subtle hint of threat. The spring before the end of book club someone called my mentor and told her that my badge was at risk for having said something to a student about volunteering at the prison. The student had a family member who worked at the prison, who then told someone, and someone called someone else who then told someone else-which finally ended with the phone call to my mentor. No one was ever able to provide any solid evidence of any wrongdoing, but the encounter did what it was meant to do: provide a warning that I was being watched. I have been warned about writing about the facility; I cannot name the people or the facility, I have been careful in leaving out specific details because I worry about those who continue to volunteer. What I witnessed was troubling and will always haunt me. My scholarship didn't allow me to think my way out of the walls, and I am ashamed to admit that though I cried at our last book club meeting (as I promised the men I would), I felt a small measure of relief. I no longer had to fight this particular battle.

At the $20^{\text {th }}$ anniversary Inside-Out ${ }^{6}$ conference I had the privilege to attend two panels: one, held at a wealthy, liberal arts college hosted by two well-educated white speakers, a lawyer and a social justice

\footnotetext{
${ }^{6}$ Inside-Out is a program developed at Temple University that believes pairing inside (imprisoned) students with outside students in college classrooms held inside prisons fosters unparalleled transformation.
} 
professor. The other was held inside a maximum-security facility and hosted formerly incarcerated men and one woman, most of whom were black. The first panel was aimed toward audiences more like me, those familiar with the work and efforts of prison reform, the theories and studies revealing the inequities within the criminal justice system, and the problems with mass incarceration. The other panel was not for me, but I was a lucky bystander. The other panel reviewed the same topics, but demanded that the incarcerated men in attendance send out some "fucking warriors." ${ }^{7}$ As I reflected on my experiences I realized I had to rethink my approach to my position in carceral studies. My role has to be limited; I am qualified to teach literature written about the criminal justice system, I am qualified to teach writing and in teaching writing study texts written about topics related to carceral studies, and I have permission to write about my own experiences with the criminal justice system-nothing more, nothing less.

Academic service commonly addresses the needs of the department-advising, program and curriculum development, graduation and/or retention numbers, or assessment-but in choosing to link my service and research, I have chosen a much less reliable system. More importantly, I have chosen to negotiate two powerful institutions, both of which demand that I be complicit to systemic bureaucracies that maintain hierarchical structures. While I have thus far labeled my work at the prison as service, given my publication history, I have learned that I cannot maintain a strict or clear line between service and research, and with that knowledge comes other uneasy conclusions. I have learned that the work I do demands that I establish boundaries for myself. For example, I cannot and should not be the voice for imprisoned men and women. I cannot work or be paid for my services by the Department of Justice or the Bureau of Prisons; I am already skirting the line by working with staff to provide programming. And I am not sure if the prison is where I need to be. My colleagues and I have begun thinking more about restorative justice and reentry work. It might be that book clubs could operate outside walls with more ease, but it hurts my heart to think about the men inside who desperately need the support and community of a book club.

With or without the line designating service from research, I also realized that my relationship with the staff complicated my relationship with the men in the book club. The staff wanted me to be an ally, so do the men. For example, the staff repeatedly asked that book club leaders help make decisions about who can join book club and to help outline policies for staying in book club. I couldn't do that work; I couldn't be the one deciding who could read a book and who could not. They wanted to know the men beyond the room of book club. I didn't want to know who they were or what they had done outside of our circle. The circle was sacred for me, which meant I could not be a friend to the staff nor could I do anything that might risk allowing the men the momentary freedom of existing in the moment of book club. The men needed us to hear their complaints, to listen to them with sympathy and treat them like, in their words, men. It was suggested that my rejection led to distrust and a lack of support for continuing book club programming. I don't know if that is the case, but in the end it doesn't matter. My uneasy conclusion is that prison demands of us more than we can give.

While I currently enjoy a strong mentor, and I had the pleasure to work at an institution that valued APBP and the work we do, this may not always be the case. I didn't have to justify the days off to go work in prison. I didn't have to justify my social justice and service learning-based coursework. I did eventually ask for specific course schedules to accommodate the book club schedule and a kind supporter of APBP's work made the change. I am not sure if this is enough though, and really, I already know it isn't. Though I want to remain true to my identity as a public scholar and I am committed to social justice, I don't know how I will find sources of hope, or more importantly, sources for the more important resources-money and time-to maintain the balance between work and life. Right now it feels like enough to have created an amazing community of learners inside the prison.

Every day inside is a good day. However, work has not set me free, and perhaps I end this wondering if it is not truly a work/life balance I seek, but a work-life ideal that incorporates activism in such a way that I have a life outside of work. Until such a discovery I will continue to pull up my too baggy prison pants and tie up my sad shoes, I will lead the meetings and participate in the tough conversations, I will blend social justice into my teaching, and I will write-and for now, it is enough to do so alongside the APBP family, my mentors and fellow volunteers, and the many supporters we have cultivated at West Virginia University. Maybe, just maybe, I have written myself into believing that the value of public scholarship is sharing the labor of thinking about how to make change happen.

\footnotetext{
${ }^{7}$ As said by Shaka Senghor to the imprisoned men at Graterford.
} 


\section{Competing Interests}

The author has no competing interests to declare.

\section{References}

Baucher, Todd. "West Virginia declares state of emergency over jail staffing." Associated Press, 29 Dec. 2017. www.thenewscenter.tv/content/news/WV-Governors-order-allows-use-of-National-Guard-to-staffregional-jails.html. Accessed January 12018.

Flaherty, Colleen. "Relying on Women, Not Rewarding Them." Inside Higher Ed, 12 April 2017. www. insidehighered.com/news/2017/04/12/study-finds-female-professors-outperform-men-service-theirpossible-professional. Accessed December 312018.

Free Minds: Book Club and Writing Workshop. Free Minds. http://freemindsbookclub.org/. Accessed 1 January 2018.

Garland, David. Peculiar Institution: America's Death Penalty in An Age of Abolition. Belknap Press, 2012. DOI: https://doi.org/10.2307/j.ctvjnrt2s

Jaschilk, Scott. "The Gender Gap on Service." Inside Higher Ed, 12 Jan. 2011, www.insidehighered.com/ news/2011/01/12/new_study_finds_unequal_distribution_by_gender_in_academic_service_work. Accessed 1 January 2018.

Lorde, Audre. “The Master's Tools Will Never Dismantle the Master's House." History is a Weapon, 1979. www. historyisaweapon.com/defcon1/lordedismantle.html. Accessed January 12018.

How to cite this article: Hammond, YS 2019 Prison Days: Observations and Reservations of a Public Scholar. Anthurium, 15(2): 4, 1-10. DOl: https://doi.org/10.33596/anth.387

Published: 23 September 2019

Copyright: ( 2019 The Author(s). This is an open-access article distributed under the terms of the Creative Commons Attribution 4.0 International License (CC-BY 4.0), which permits unrestricted use, distribution, and reproduction in any medium, provided the original author and source are credited. See http://creativecommons.org/licenses/by/4.0/. 